\title{
Plankton crustaceans in bays with different trophic status in Llanquihue lake $\left(41^{\circ} \mathrm{S}\right.$ Chile)
}

\author{
P. De los Ríos Escalante ${ }^{a, b *}$, D. Soto ${ }^{c}$, R. Santander-Massa ${ }^{d}$ and \\ P. Acevedo $o^{e, f}$ \\ ${ }^{a}$ Laboratorio de Ecología Aplicada y Biodiversidad, Escuela de Ciencias Ambientales, Facultad de Recursos Naturales, \\ Universidad Católica de Temuco - UCTemuco, Casilla 15-D, Temuco, Chile \\ bNúcleo de Estudios Ambientales, Universidad Católica de Temuco - UCTemuco, Casilla 15-D, Temuco, Chile \\ ${ }^{c}$ Senior Fisheries Officer Inland Water Resources and Aquaculture Service - FIRI, Fisheries Department, FAO of UN, \\ Via delle Terme di Caracalla, I-00100, Roma, Italia \\ dPrograma de Ciencias Forestales, Universidad Austral de Chile, Valdivia, Chile \\ ${ }^{e}$ Center for Optics and Photonics, Universidad de Concepción - UdeC, Casilla 160-C, Concepción, Chile \\ fDepartamento de Física, Facultad de Ciencias e Ingeniería, Universidad de la Frontera - UFRO, \\ Casilla 54-D, Temuco, Chile \\ *e-mail: prios@uct.cl
}

Received: October 1, 2015 - Accepted: April 18, 2016 - Distributed: August 31, 2017

(With 2 figures)

\begin{abstract}
The Llanquihue lake is included in the called Araucanian or Nord Patagonian lakes located between $38-41^{\circ} \mathrm{S}$. These lakes are characterized by their oligo-mesotrophic status due to human intervention which takes to the increase in nutrients inputs from industries and towns. Effects on zooplankton assemblages are observed with marked increase of daphnids abundance. The aim of the present study is to analyze the trophic status and zooplankton relative abundance in different bays of Llanquihue lake. It was found direct associations between chlorophyll a with daphnids percentage, total dissolved nitrogen with reactive soluble phosphorus nitrogen/phosphorus molar radio with cyclopoids percentage, and an inverse relation between daphnids and calanoids percentages. The occurrence of three kinds of microcrustacean assemblages and environmental conditions was evidenced: the first one with high calanoids percentage, low species number and low chlorophyll and nutrients concentration, a second with moderate chlorophyll and nutrients concentration and moderate daphnids percentage; high species number and a third site with high chlorophyll and nutrients concentration, high daphnids percentage and high species number. Daphnids increase under mesotrophic status, agree with similar results observed for southern Argentinean and New Zealand lakes.
\end{abstract}

Keywords: zooplankton, trophic conditions, daphnids, calanoids.

\section{Crustáceos planctónicos crustáceo em baías com estado trófico diferente no lago Llanquihue $\left(41^{\circ} \mathrm{S}\right.$ Chile $)$}

\section{Resumo}

O lago Llanquihue está incluído nos chamados lagos araucana ou Nord Patagônia localizado entre $38-41^{\circ} \mathrm{S}$. Estes lagos são caracterizados pela condicao oligo-mesotrofica debido a intervencao humana, com aumento da carga de nutrientes provenientes de industrias y areas urbanas com efeitos sobre as assembleias zooplantonicas sao observadas, com aumento acentuado de dafnideos. O objetivo do presente estudo é analisar o estado trófico a abundancia relative do zooplancton em diferentes compartimentos do lago Llanquihue. Foram encontradas associações diretas entre clorofila a com percentual de dafinídeos, nitrogênio total dissolvido com fósforo solúvel reativo molares razao molar nitrogênio / fósforo com percentual de ciclopóides, e uma relação inversa entre percentuais de dafinídeos e calanóides porcentagens. A ocorrência de três tipos de assembleias de microcrustáceos e as condições ambientais fora: a primeira com alta porcentais de calanóides, baixo número de espécies e baixa clorofila e a nutrientes, uma segunda com concentracoes moderadas de clorofila e nutrientes percentual moderado de daphnideos e alto número de espécies; e uma terceiro local com alta concentração de clorofila e nutrientes, alta abundância dafinídeos e número elevado de espécies. Resultados similares com aumento de dafnideos em condicoes mesotroficas também foram observados para lagos da Argentina e Nova Zelândia do sul.

Palavras-chave: zooplâncton, condições tróficas, dafinídeos, calanóides. 


\section{Introduction}

The called Araucanian or Nord Patagonian lakes are located in Argentina and Chile between $38-41^{\circ} \mathrm{S}$, these lakes are characterized by their oligo or oligomesotrophic status, and glacial origin (Thomasson, 1963). These lakes have low zooplankton species number with marked higher calanoid abundance compared to daphnids in oligotrophic status which can observed under oligomesotrophic status (Modenutti et al., 1998; De los Ríos-Escalante, 2010).

These lakes located in Chile has marked human intervention due to changes in their surrounding basins, because the original native forest was replaced by towns, agricultural, and industrial activities, with consequent nutrient inputs (Soto, 2002). These increases were accentuated during the last three decades (Woelfl et al., 2003), and generate changes in zooplankton composition. In the last decades it was found an increase in species number, daphnids percentage and low calanoid percentage (De los Ríos-Escalante, 2010).

In some lakes with small bays it was found different gradient of trophic status due nutrients inputs associated to presence/absence of human intervention, such as was observed for Llanquihue lake (Soto, 2002). The effects of these alterations in trophic status on zooplankton assemblages were previously described (De los Ríos, 2003), and it was reported preliminary an increase of daphnids abundance in bays with towns or aquaculture activities. The aim of the present study is to analyze the zooplankton assemblages in different bays of Llanquihue lake in order to determine the potential role of nutrient and chlorophyll concentration on distinct zooplankton groups abundance.

\section{Material and Methods}

Th sampling sites were visited once, between December 2001 and March 2002. These sites correspond to different bays in Llanquihue lake with towns, aquaculture and with absence of marked human intervention (Figure 1; Table 1). Nutrient and chlorophyll samples were taken for each site and analyzed according to Wetzel and Likens (1991). Zooplankton samples were taken using $20 \mathrm{~m}$ vertical hauls with a plankton net of $20 \mathrm{~cm}$ diameter and $100 \mu \mathrm{m}$ mesh size, and fixed with ethanol absolute. For analysis were considered the following groups daphnids (Daphnidae family), other cladocerans (Sididae and Bosminidae family), calanoids (Centropagidae and Diaptomidae) and cyclopoids. Specimens were identified with help of specialized literature (Araya and Zúñiga, 1985; Reid, 1985; Bayly, 1992).

\subsection{Data analysis}

Data on nutrients and chlorophyll concentrations, daphnids, cladocerans, calanoid and cyclopoids percentages were analyzed using Statgraphics Centurion software, in order to determine the grouping variables, using a principal component analysis (PCA). In a second step, the Checkerboard score ("C-score") was calculated, which is a quantitative index of occurrence that measures the extent to which species co-occur less frequently than expected by chance (Gotelli, 2000, 2001). A community is structured by competition when the C-score is significantly larger than expected by chance (Gotelli, 2000, 2001). Finally, the co-occurrence patterns were compared with null expectations via simulation. Gotelli and Entsminger (2007) and Gotelli (2000) suggested the following robust statistical null models: (1) Fixed-Fixed: in this model the
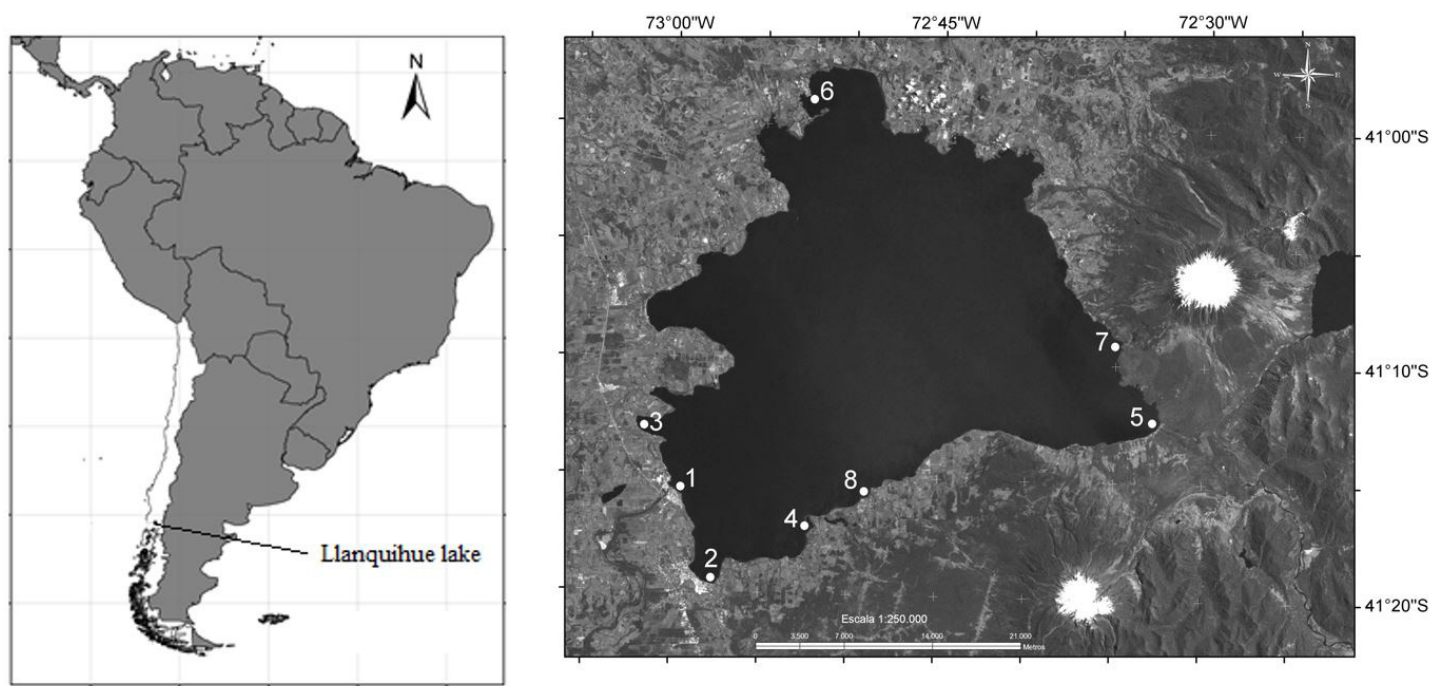

Figure 1. Map of localization of Llanquihue lake, and sites considered in the present study (1: Llanquihue town; 2: Puerto Chico bay; 3: Puerto Phillippi bay; 4: Puerto Rosales bay; 5: Ensenada bay; 6: Puerto Octay town; 7: Volcanes bay; 8: Venado beach). 


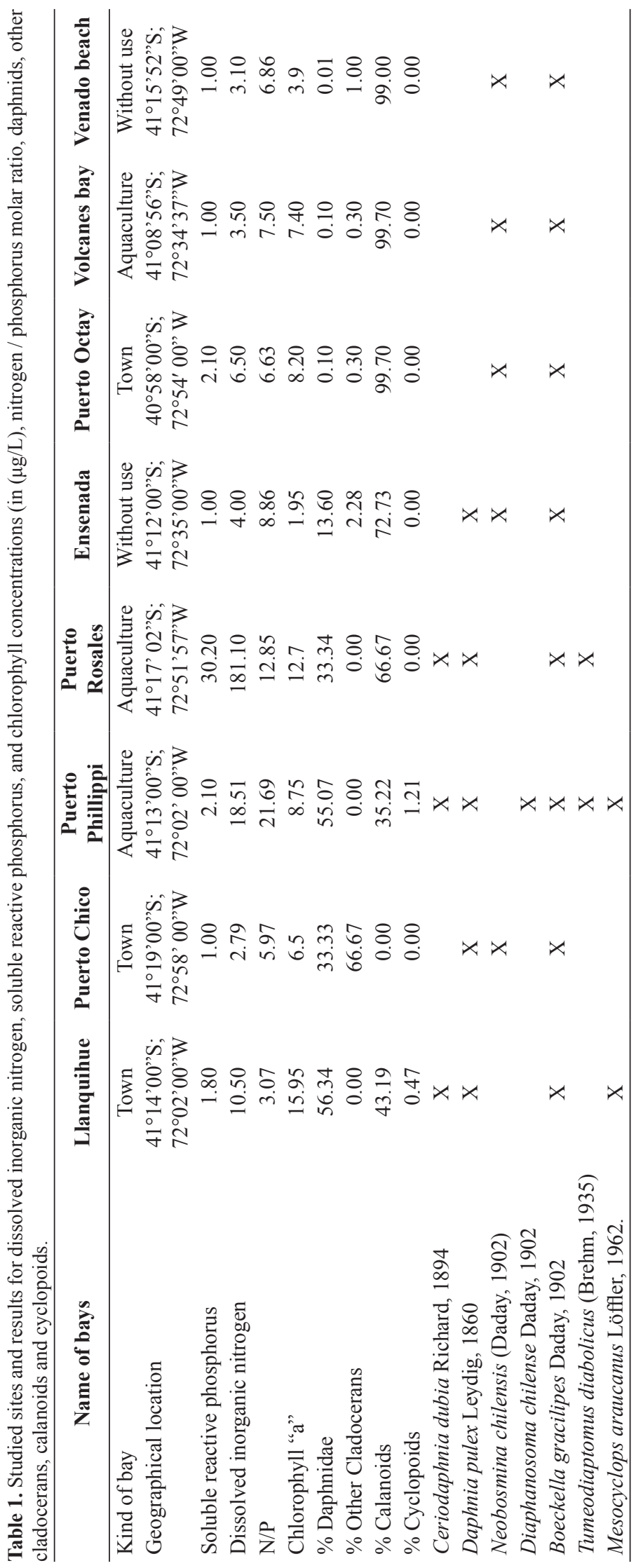


row and column sums of the matrix are preserved. Thus, each random community contains the same number of species as the original community (fixed column), and each species occurs with the same frequency as in the original community (fixed row). (2) Fixed-Equiprobable: in this algorithm only the row sums are fixed and the columns are treated as equiprobable. This null model considers all the samples (columns) as equally available for all species. (3) Fixed-Proportional: in this algorithm the species occurrence totals are maintained as in the original community, and the probability that a species will occur at a site (column) is proportional to the column total for that sample. The null model analyses were performed using Ecosim version 7.0 software (Gotelli and Entsminger, 2007; Tiho and Josens, 2007; Tondoh, 2006).

Finally, the available data was ordered for apply species richness estimation considering presence/absence data using the software SPADE with the aim of understanding the community properties (Chen and Chen, 2010), considering k $=3$ as limit number for rare species because the crustacean zooplankton in southern Patagonia exhibits low species number (De los Ríos-Escalante, 2010).

\section{Results}

The results shown in Table 1 denote the association of oligo-mesotrophic status with high daphnids percentage in sites near to towns and bays with aquaculture activities.
Conversely, in zones without human intervention it was observed low nutrients and chlorophyll concentration and low daphnids abundances. The species reported revealed that Daphnia pulex occurred in many aquaculture and towns sites, whereas Ceriodaphnia dubia was present in practically all sites, similar to Boeckella gracilipes. Whereas Tumeodiaptomus diabolicus was present only in two aquaculture sites, Neobosmina chilensis occurred mainly in less polluted sites, and finally Mesocyclops araucanus was present mainly in mesotrophic sites (Table 1).

The Pearson index correlation matrix generated by PCA shows direct significant correlations between dissolved inorganic nitrogen and reactive soluble phosphorus, daphnids percentage with chlorophyll "a" concentration", daphnids percentage with cyclopoids percentage and nitrogen/phosphorus molar ratio with cyclopoids abundance, species number with N/P ratio, and daphnids with cyclopoids percentages. It was found significant inverse associations between calanoids percentage with daphnids and other cladocerans percentage (Table 2). The main variables correlated to the first axis were species number, daphnids and cyclopoids percentage and chlorophyll concentration. The main variables correlated to the second axis were total inorganic nitrogen, soluble reactive phosphorus and calanoid percentage (Table 3). The results of PCA revealed the presence of two main groups, one representing sites with low nutrient and

Table 2. Pearson correlation index matrix generated by PCA of variables considered in the present study (values in bold denotes significant correlations; $\mathrm{p}<0.05)$.

\begin{tabular}{|c|c|c|c|c|c|c|c|c|}
\hline Variables & $\begin{array}{c}\text { Dissolved } \\
\text { inorganic } \\
\text { nitrogen }\end{array}$ & $\mathbf{N} / \mathbf{P}$ & $\begin{array}{l}\text { Chlorophyll } \\
\text { "a" }\end{array}$ & $\begin{array}{c}\% \\
\text { Daphnidae }\end{array}$ & $\begin{array}{c}\text { \% Other } \\
\text { Cladocerans }\end{array}$ & $\begin{array}{c}\% \\
\text { Calanoids }\end{array}$ & $\begin{array}{c}\% \\
\text { Cyclopoids }\end{array}$ & $\begin{array}{l}\text { Species } \\
\text { number }\end{array}$ \\
\hline $\begin{array}{l}\text { Soluble reactive } \\
\text { phosphorus }\end{array}$ & 0.9 & 0.2 & 0.4 & 0.1 & -0.1 & 0.0 & -0.1 & 0.2 \\
\hline $\begin{array}{l}\text { Dissolved inorganic } \\
\text { nitrogen }\end{array}$ & & 0.3 & 0.4 & 0.2 & -0.1 & -0.1 & -0.1 & 0.3 \\
\hline $\mathrm{N} / \mathrm{P}$ & & & -0.1 & 0.3 & -0.2 & -0.1 & 0.7 & 0.7 \\
\hline Chlorophyll "a" & & & & 0.6 & -0.1 & -0.2 & 0.3 & 0.4 \\
\hline$\%$ Daphnidae & & & & & 0.1 & -0.7 & 0.7 & 0.8 \\
\hline$\%$ Other Cladocerans & & & & & & -0.7 & -0.2 & 0.0 \\
\hline$\%$ Calanoids & & & & & & & -0.3 & 0.6 \\
\hline \% Cyclopoids & & & & & & & & 0.8 \\
\hline
\end{tabular}

Table 3. Scores of importance of PCA factors.

\begin{tabular}{lcc}
\hline & Component 1 & Component 2 \\
\hline Soluble reactive phosphorus & -0.1 & -0.5 \\
Dissolved inorganic nitrogen & -0.2 & -0.5 \\
N/P & -0.3 & -0.1 \\
Chlorophyll “a” & -0.3 & -0.2 \\
\% Daphnidae & -0.4 & 0.1 \\
\% Other Cladocerans & 0.1 & 0.3 \\
\% Calanoids & 0.3 & -0.3 \\
\% Cyclopoids & -0.3 & 0.2 \\
Species number & -0.4 & 0.1 \\
\hline
\end{tabular}


chlorophyll concentrations and high calanoid percentage (Ensenada, Venado, Volcanes and Puerto Octay bays), and a second group with moderate to high nutrient and chlorophyll concentrations and moderate to high daphnids percentage and low calanoids percentage (Llanquihue, Puerto Phillippi and Puerto Chico Bays), and a third site corresponding to Puerto Rosales bay, an isolated eutrophic bay with high daphnids percentage (Figure 2).
The results of the co-occurrence null model analysis revealed the presence of regulator factors only for fixed-fixed model (Table 4), that would partially agree with the results of PCA analysis of strong driving force acting on crustacean communities. The species richness estimations, based on presence-absence data, revealed were weakly higher than the total species number reported, but the variation range was relatively wide (Table 5).

Table 4. Results of null model co-occurrence species for data included in the present study ("p" values lower than 0.05 denotes the existence of regulator factors in species associations).

\begin{tabular}{lcccc}
\hline \multicolumn{1}{c}{ Model } & Observed index & Mean index & Standard effect size & P \\
\hline Fixe-fixed & 2.4 & 1.7 & 5.7 & $<0.01$ \\
Fixed-proportional & 2.4 & 1.8 & 1.2 & 0.12 \\
Fixed-equiprobable & 2.4 & 2.0 & 0.8 & 0.24 \\
\hline
\end{tabular}

Table 5. Results of estimated biodiversity parameters obtained from SPADE software.

\begin{tabular}{lccc}
\hline \multicolumn{1}{c}{ Estimator } & Estimate & Estimate standard error & 95\% confidence interval \\
\hline Homogeneous model & 7.6 & 1.0 & $(7.1-13.1)$ \\
Chao2 & 7.2 & 0.7 & $(7.0-11.3)$ \\
Chao2-bc & 7.0 & 0.1 & $(7.0-7.0)$ \\
Model 1(h) & 7.3 & 0.8 & $(7.0-12.1)$ \\
Model 1(h)-1 & 7.3 & 0.8 & $(7.0-12.1)$ \\
Model (th) & 7.2 & 0.8 & $(7.0-12.7)$ \\
Model (th)-1 & 7.2 & 1.0 & $(7.0-13.5)$ \\
$1^{\text {st }}$ Order jackkniffe & 7.9 & 1.3 & $(7.0-14.1)$ \\
$2^{\text {nd }}$ Order jackkniffe & 7.3 & 2.0 & $(7.0-20.5)$ \\
\hline
\end{tabular}
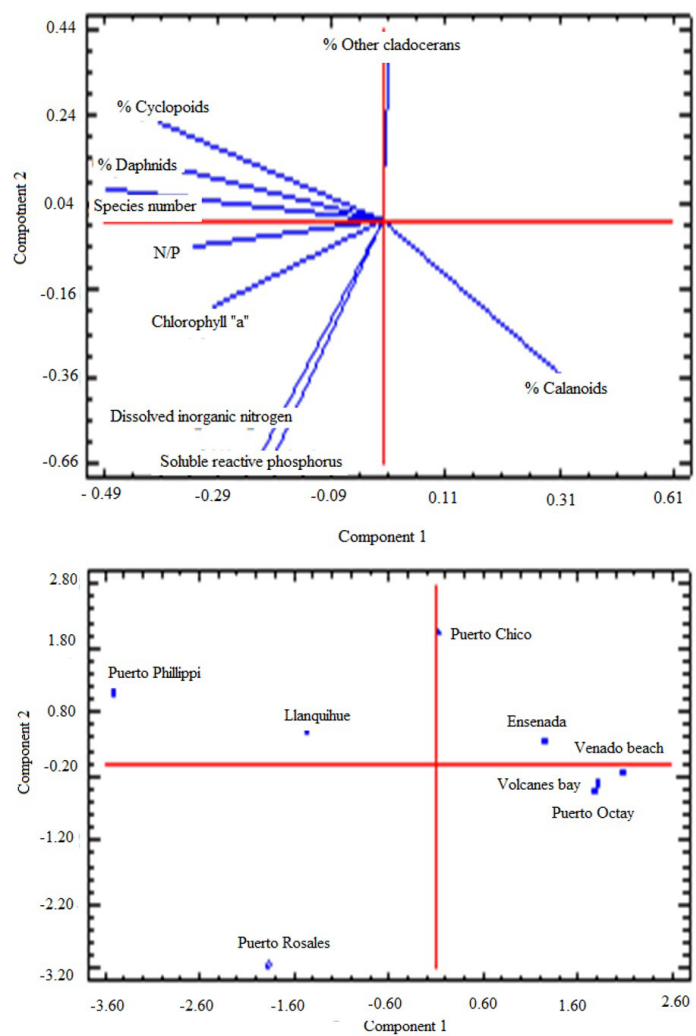

Figure 2. Results of PCA analysis for variables and sites considered in the present study. 


\section{Discussion}

The results revealed that nutrient and chlorophyll increases had a positive influence on daphnids and cyclopoids percentage, such as observed for North Patagonian lakes (Woelfl, 2007; De los Ríos-Escalante, 2010). In Patagonia there are numerous oligotrophic lakes with low species number, low daphnids abundance and high calanoid dominance in their zooplankton assemblages (Soto and Zúñiga, 1991; Kamjunke et al., 2009; De los Ríos-Escalante, 2010). The trophic status of Llanquihue was based on first studies was carried out in Ensenada Bay and it was described as oligotrophic (Campos et al., 1988). Nevertheless the study of Soto (2002) described this lake based on the analyses of bays under towns and aquaculture influence and a control site in the center of the lake, and it observed that zones with human interference exhibited increases in total phosphorus and chlorophyll concentrations. In a first studies with zooplankton assemblages it was found increase in daphnids abundances in lakes between $39-41^{\circ} \mathrm{S}$ with higher chlorophyll concentrations (Soto and Zuñiga, 1991; De los Rios-Escalante, 2010). In this context, Llanquihue lake has a gradient of chlorophyll concentration due human intervention in their surrounding basins. Despite that there is low dissolved organic matter concentrations, as other regionally similar lakes in Argentinean and Chilean Patagonia (Balseiro et al., 2007; De los Rios-Escalante, 2010). Therefore, the chlorophyll concentration, in spite of the kind of phytoplankton composition, can be an important as regulator factor for zooplankton abundances in Argentinean Patagonian lakes (Trochine et al., 2015).

Our results concerning Daphnids and other cladocerans (Bosminidae and Sididae families), are supported by Modenutti et al. (1998) who described opposite zooplankton abundances responses between Ceriodaphnia dubia and Neobosmina chilensis. The direct association between daphnids and cyclopoids percentage associated to chlorophyll increase was described for Chilean North Patagonian lakes (Woelfl, 2007; De los Ríos-Escalante, 2010). Similar results were described for New Zealand lakes that have similar latitude and geographical characteristics of Nothofagus forests (Jeppesen et al., 1997, 2000).

Other important factor to be considered is the fish predation on zooplankton composition (Modenutti et al., 1998). In unpolluted conditions the calanoids copepods would have an important role as grazer on phytoplankton and in turn would be eaten by zooplanktivorous fishes in Argentinean and Chilean Patagonian lakes (Soto and Zuñiga, 1991; De los Rios-Escalante, 2010; Reissig et al., 2015; Trochine et al., 2015). Additionally, the natural ultraviolet radiation exposure that increased in Patagonia affect zooplankton assemblages because the species have different tolerance to UV radiation under trophic gradient (Marinone et al., 2006; De los Ríos-Escalante, 2010; Hylander et al., 2012). Then considering both view point, the zooplankton composition can be regulated by trophic variations, ultraviolet radiation exposure and fish predation.
The predicted results about species richness indicate that species number is independent of sampling replicates (Gongalsky et al., 2006). Thus, probably the species richness estimators would agree with null models, because first null models revealed the presence of many species repeated in many of sampled sites, and the species richness estimators would indicate that the species number would not vary. These results would agree with the descriptions about Chao 1 and Chao 2 index that is a robust estimator (Cannon et al., 1998; Martinez-Aquino et al., 2011; Hoshi et al., 2014).

Our study revealed that zooplankton assemblages are associated to chlorophyll gradients in bays with different kind of human intervention. These results can be the base for future studies about spatial heterogeneity and trophic status in Patagonian lakes with difererent human interference, towards future environmental management and sustainable use.

\section{Acknowledgements}

The present study was founded by projects DID UACH d2011-11; CONICYT Chile (Doctoral Fellowship); IAI (Enhanced ultraviolet $\mathrm{B}$ radiation in natural ecosystems as an added perturbation due ozone depletion) and MECESUP UCT 0804, and M.I for her valuable comments and suggestions for improve the manuscript.

\section{References}

ARAYA, J.M. and ZÚÑIGA, L.R., 1985. Manual taxonómico del zooplancton lacustre de Chile. Boletín Informativo Limnológico, vol. 8, pp. 1-110.

BALSEIRO, E., MODENUTTI, B., QUEIMALIÑOS, C. and REISSIG, M., 2007. Daphnia distribution in Andean Patagonian lakes: effect of low food quality and fish predation. Aquatic Ecology, vol. 41, no. 4, pp. 599-609. http://dx.doi.org/10.1007/ s10452-007-9113-3

BAYLY, I.A.E., 1992. Fusion of the genera Boeckella and Pseudoboeckella and a revision of their species from South America and subantarctic islands. Revista Chilena de Historia Natural, vol. 65, no. 1, pp. 17-63.

CAMPOS, H., SOTO, D., STEFFEN, W., AGÜERO, G., PARRA, O. and ZÚÑIGA, L., 1988. Limnological study of lake Llanquihue (Chile): morphometry, physics, chemistry and primary productivity. Archiv für Hydrobiologie, vol. 81, suppl., pp. 37-67.

CANNON, C.H., PEART, D.R. and LEIGHTON, M., 1998. Tree species diversity in commercial logged Bornean rainforest. Science, vol. 281, no. 5381, pp. 1366-1368. http://dx.doi.org/10.1126/ science.281.5381.1366. PMid:9721105.

CHEN, A. and CHEN, T.J., 2010 [viewed 1 October 2015]. Program SPADE (Species Prediction and Diversity Estimation): program and user's guide [online]. Taiwan: Institute of Statistics. Available from: http:chao.stat.nthu.edu.tw

DE LOS RÍOS, P., 2003. Efecto de las disponibilidades de recursos energéticos, estructurales y protección sobre la distribución y abundancia de copépodos y cladóceros zooplanctónicos lacustres chilenos. Valdivia: Universidad Austral de Chile. 
DE LOS RÍOS-ESCALANTE, P., 2010. Crustacean zooplankton communities in Chilean inland waters. Crustaceana Monographs, vol. 12 , pp. 1-109.

GONGALSKY, K.B., MIDTGAARD, F. and OVERGAARD, H.J., 2006. Effects of prescribed forest burning on carabid beetles (Coleoptera: Carabidae): a case study in south-eastern Norway. Entomologica Fennica, vol. 17, no. 3, pp. 325-333.

GOTELLI, N.J. and ENTSMINGER, G.L., 2007 [viewed 1 October 2015]. EcoSim: null models software for ecology. Version 7 [online]. Jericho: Acquired Intelligence Inc. \& Kesey-Bear. Available from: http://garyentsminger.com/ecosim.htm

GOTELLI, N.J., 2000. Null models of species co-occurrence patterns. Ecology, vol. 81, no. 9, pp. 2606-2621. http://dx.doi. org/10.1890/0012-9658(2000)081[2606:NMAOSC]2.0.CO;2.

GOTELLI, N.J., 2001. Research frontiers in null model analysis. Global Ecology and Biogeography, vol. 10, no. 4, pp. 337-343. http://dx.doi.org/10.1046/j.1466-822X.2001.00249.x.

HOSHI, T., IMANISHI, N., HIGA, Y. and CHAVES, L.F., 2014. Mosquito biodiversity patterns around urban environments in South-Central Okinawa island, Japan. Journal of the American Mosquito Control Association, vol. 30, no. 4, pp. 260-267. http:// dx.doi.org/10.2987/14-6432R.1. PMid:25843131.

HYLANDER, S., SOUZA, M.S., BALSEIRO, E., MODENUTTI, B. and HANSSON, L.A., 2012. Fish-mediated trait compensation in zooplankton. Functional Ecology, vol. 26, no. 3, pp. 608-615. http://dx.doi.org/10.1111/j.1365-2435.2012.01976.x.

JEPPESEN, E., LAURIDSEN, T.L., MITCHELL, S.F. and BURNS, C.W., 1997. Do zooplanktivorous fish structure the zooplankton communities in New Zealand lakes? New Zealand Journal of Marine and Freshwater Research, vol. 31, no. 2, pp. 163-173. http://dx.doi.org/10.1080/00288330.1997.9516755.

JEPPESEN, E., LAURIDSEN, T.L., MITCHELL, S.F., CHRISTOFFERSSEN, K. and BURNS, C.W., 2000. Trophic structure in the pelagial of 25 shallow New Zealand lakes: changes along nutrient and fish gradients. Journal of Plankton Research, vol. 22, no. 5, pp. 951-968. http://dx.doi.org/10.1093/ plankt/22.5.951.

KAMJUNKE, N., VOGT, B. and WOELFL, S., 2009. Trophic interactions of the pelagic ciliate Stentor spp. in North Patagonian lakes. Limnologica, vol. 39, no. 2, pp. 107-114. http://dx.doi. org/10.1016/j.limno.2008.08.001.

MARINONE, M.C., MARQUE, S.M., SUÁREZ, D.A., DIÉGUEZ, M.C., PÉREZ, P., DE LOS RÍOS, P., SOTO, D. and ZAGARESE, H.E., 2006. UVR Radiation as a potential driving force for zooplankton community structure in Patagonian lakes. Photochemistry and Photobiology, vol. 82, no. 4, pp. 962-971. http://dx.doi.org/10.1562/2005-09-09-RA-680. PMid:16643085.

MARTINEZ-AQUINO, A., HERNÁNDEZ-MENA, D.I., PÉREZRODRÍGUEZ, R., AGUILAR-AGUILAR, R. and PEREZ-PONCE DE LEÓN, G., 2011. Endohelminth parasites of the freshwater fish Zoogeneticus purhepechus (Cyprinodontiformes: Goodeidae) from two springs in the Lower Lerma river, México. Revista Mexicana de Biodiversidad, vol. 82, no. 4, pp. 1132-1137.

MODENUTTI, B.E., BALSEIRO, E.G., QUELIMAÑOS, C.P., AÑON-SUAREZ, D.A., DIEGUEZ, M.C. and ALBARIÑO, R.J., 1998. Structure and dynamics of food webs in Andean lakes. Lakes and Reservoirs: Research and Management, vol. 3, no. 3-4, pp. 179-186. http://dx.doi.org/10.1046/j.1440-1770.1998.00071.x.

REID, J., 1985. Chave da identificao e lista de referencias para as species continentais sulamericanas de vida livre da orden Cyclopoida. Boletim Zoológico da Universidade de São Paulo, vol. 9, pp. 17-143.

REISSIG, M., QUEIMALIÑOS, C., MODENUTTI, B. and BALSEIRO, E., 2015. Prey C:P ratio and phosphorus recycling by a planktivorous fish: advantages of fish selection towards pelagic cladocerans. Ecology Freshwater Fish, vol. 24, no. 2, pp. 214-224. http://dx.doi.org/10.1111/eff.12136.

SOTO, D.I. and ZUÑIGA, L.R., 1991. Zooplankton ensamblages of Chilean températe lakes: a comparison with North American counterparts. Revista Chilena de Historia Natural, vol. 64, no. 3, pp. 569-581.

SOTO, D.I., 2002. Oligotrophic patterns in southern Chilean lakes: the relevance of nutrient and mixing depth. Revista Chilena de Historia Natural, vol. 75, no. 2, pp. 377-393. http://dx.doi. org/10.4067/S0716-078X2002000200009.

THOMASSON, K., 1963. Araucanian lakes. Acta Phytogeographica Suecica, vol. 47, pp. 1-139.

TIHO, S. and JOSENS, J., 2007. Co-occurrence of earthworms in urban surroundings: a null models of community structure. European Journal of Soil Biology, vol. 43, no. 1, pp. 84-90. http:// dx.doi.org/10.1016/j.ejsobi.2006.10.004.

TONDOH, J.E., 2006. Seasonal changes in earthworm diversity and community structure in central Côte d'Ivoire. European Journal of Soil Biology, vol. 42, suppl. 1, pp. S334-S344. http:// dx.doi.org/10.1016/j.ejsobi.2006.09.003.

TROCHINE, C., DIAZ, C., BASTIDAS, M., BALSEIRO, E. and MODENUTTI, B., 2015. The abundance of mixotrophic algae drives the carbon isotope composition of the copepod Boeckella gracilipes in shallow Patagonian lakes. Journal of Plankton Research, vol. 37, no. 2, pp. 441-451. http://dx.doi.org/10.1093/ plankt/fbv005.

WETZEL, R., LIKENS, G., 1991. Limnological analysis. New York: Springer. $391 \mathrm{p}$.

WOELFL, S., 2007. The distribution of large mixotrophic ciliates (Stentor) in deep North Patagonian lakes (Chile): first results. Limnologica, vol. 37, no. 2, pp. 28-36. http://dx.doi.org/10.1016/j. limno.2006.08.004.

WOELFL, S., VILLALOBOS, L. and PARRA, O., 2003. Trophic Parameters and method validation in Lake Riñihue (North Patagonia: Chile) from 1978 through 1997. Revista Chilena de Historia Natural, vol. 76, no. 3, pp. 459-474. http://dx.doi. org/10.4067/S0716-078X2003000300010. 